\title{
An Analysis of Teacher Questions and Student Responses in the English Teaching-Learning Process
}

\author{
I Putu Anom Didik Susantara1, *, I Putu Ngurah Wage Myartawan²,
}

1,23 Ganesha University of Education, Indonesia

A R T I C L E I N F O

Article history:

Received 01 February

2020

Received in revised

Form 01 March 2020

Accepted 18 April 2020

Available online 30

August 2020

Keywords:

Teacher question, student response, teaching-learning

\begin{abstract}
A B S T R A C T
This study aimed to analyze the types of teacher questions, the purposes of the teacher in asking questions, and student responses to the teacher questions in the English classroom. The current study was a case study. The study involved an English teacher and seventh grade students of SMP Negeri 4 Singaraja. The data were collected through observation and interview guide. The data analysis technique used was descriptive and interactive data analysis. The result of the analysis showed that the teacher more frequently asked convergent and display questions rather than divergent and referential questions. Procedural questions were also found. The teacher's questions served several purposes such as to develop students' interests and curiosity, to examine students' knowledge, and to diagnose student difficulties in the learning process. Discussions and suggestions are further presented in this paper.
\end{abstract}

\section{Introduction}

In the teaching and learning process, there is communication between the teacher and students as a form of interaction. Interaction is a process of exchanging information between one individual with another individual (Kalantari, 2009). This interaction in the context of learning takes the form of discussions or lectures to convey learning material (Rido \& Sari, 2018; Vebriyanto, 2015). In addition, the purpose of interaction is to maintain class activity so that learning objectives can be achieved (Liskinasih, 2016; Sundari, 2017).

In the 2013 curriculum, learning interactions always involve questioning activity. Questioning is important aspects of classroom interaction (Nurpahmi, 2017; Sari \& Hasibuan, 2019). Questioning refers to strategies of collecting and understanding information about students' development, ability and competency (Astrid et al., 2019). This questioning activity in classroom is important to develop students critical thinking, creative thinking ability, and higher level thinking skills (Shaunessy, 2005; Zulkifli \& Hashim, 2019). Padmadewi, Artini and Agustini (2017) add that the purpose of questioning is to develop students' interests and curiosity, to get student attention, to evaluate student preparation, to review and summarize previous lessons or subtopics, to assess student achievement, diagnose student difficulties in the learning process, and to motivate and attract student activity. Through questioning, teachers takes a role to be a facilitator and motivator, where communicative competence is one of the competences that need to be achieved (Vusparatih, 2014).

There are several types of question. The types of the questions used by the teacher are important since they determines the range opportunity of the students to use the target language which is through answering the questions (Erlinda \& Dewi, 2014; Etemadzadeh et al., 2013). Kao (2012) state that there are two types of questions that are based on the nature of the interaction, namely referential questions and display questions. Display questions or also called pseudo are questions that usually require short and simple answers. This is used to check students' knowledge or to recall previous knowledge or information. Referential questions are the opposite of display or pseudo questions. Referential questions or also called original questions aim to obtain information unknown to the recipient. In the teaching and learning process, the teacher asks reference questions to get student answers based on opinions, judgments, and 
real life experiences where their function is to fill the information gap. Referential question answers are usually longer and more complex than display questions. The other type of questions are open/closed ended question and yes/no question. Open ended questions can have more than one acceptable answer while close ended question can accept only one answer (Yang, 2010). In yes/no questions, the answer or response required either yes or no (Usenbo, 2017). Based on students' response, there are convergent and divergent questions (Döş et al., 2016). Convergent questions requires a single short-correct answer. Divergent questions are similar with open-ended questions, which may require a multiple answer. Seeing the definition presented above, it can be said that display questions are similar with convergent and openended questions, whereas referential questions are similar with divergent and open-ended questions. In terms of the answers or responses needed, close-ended questions correspond to yes / no questions.

Several studies have found these types of questions in interactions during the learning process. Rachmawaty and Ariani (2019) found that English teachers frequently ask yes/no question to check students' understanding towards learning material. Paramartha, Ramawati, and Suputra (2018) identified that English teacher in junior high school more frequently asked convergent, closed, and display questions. Omari (2018) identified that in honing critical thinking skill, the English teacher dominantly used open-ended questions during the teaching and learning process.

Looking at the importance of questioning and the benefit that it brings to the classroom, investigate the types of questions used by English teachers during the teaching and learning process, the purpose of the teacher in using such questions, and student responses in response to teacher questions. Result of the present study is expected to give more contribution to the existing literature of types of questions used in English language teaching and learning classroom.

\section{Methods}

The present study is a case study. A case study deals with an investigation toward particular situation to acquire information on how and why those situation occurs (Crowe et al., 2011). The study was conducted at SMPN 4 Singaraja. The participant of the study was seven grade English teachers and students. A classroom observation and interview guide were conducted to collect the data. The data from the result of observation were descriptively analysed. In this study, the three types of questions that form the basis of analysis are yes / no, convergent and divergent. The data from interview were analysed using interactive model analysis by Miles, Huberman, and Saldana 2014). The interactive model analysis consists of four steps namely 1) data collection, 2) data reduction, 3) data display, and 4) conclusion drawing.

To avoid irregularities in the results of this study, researchers used Triangulation to make the research results valid and reliable. In this study, researchers used the methodological triangulation. Methodological triangulation refers to use different of method in acquiring information in a study (Merriam \& Tisdell, 2016). The two-method used in this study were observation and interview.

\section{Result and Discussion}

In the study, it was found that the number of questions given by teachers to students either individually or in groups were 181 questions. The detail of the data is presented in table 1.

Table 1. The number of Questions Identified

\begin{tabular}{lcccc}
\hline Observation & \multirow{2}{*}{ Number of Questions Occur } & \multicolumn{3}{c}{ Type of Questions } \\
\cline { 3 - 5 } & & Yes/no & Convergent & Divergent \\
\hline $1^{\text {st }}$ & 72 & 9 & 40 & 23 \\
$2^{\text {nd }}$ & 47 & 11 & 33 & 3 \\
$3^{\text {rd }}$ & 62 & 12 & 43 & 7 \\
Total & $\mathbf{1 8 1}$ & 32 & 116 & 33 \\
Percentage & & $17,68 \%$ & $64,08 \%$ & $18,22 \%$ \\
\hline
\end{tabular}

From table 1, it can be seen that the most frequent questions used by English teacher was convergent questions. From the total of 181 questions, $116(64,08 \%)$ questions belong to convergent question. This is followed with $33(18,22 \%)$ divergent questions and $32(17,68 \%)$ yes/no question.

In the present study, the convergent questions were the most frequent questions asked by teacher. It was identified that the convergent questions were asked $116(64,08 \%)$ times. Convergent questions used to check student knowledge for example; "what is smooth?" "What is the meaning of small?" students 
will response it with short answers. The other example of convergent questions used by teacher "what did you read today?" or "what do have in your bag?" This was similar with the study conducted by Paramartha et al., (2018) who identified that the teachers more often raise convergent questions to the students. Erlinda and Dewi (2014) also found that convergent questions were preferred by English teacher. From the result of interview, the teacher said that using convergent questions was to develop students interest and curiosity in teaching and learning process. They also said that the use of convergent questions were merely to brainstorm the students and to check their preparation in learning. Besides that, the use of convergent questions are to encourage students' thinking and focus on the content of the learning (Aqil, 2017). Padmadewi et al., (2017) supports that convergent questions can interact students' interest and keep the students focus with the content of teaching and learning.

The second most used question identified in this study was divergent questions. The divergent questions were asked $33(18,22 \%)$ times during observation of teaching and process. The example of divergent questions were "what do you understand about announcement", and "What do you think about the online learning?". The use of divergent question This was in line with a study that was conducted by Qashoa (2013) who found that teacher and students' interaction dominantly involves divergent questions. The teacher said that, they tried to develop students' critical thinking by raising an analytic question. They also expressed that, even though the questions were difficult, this would motivate students to think in order to give appropriate answers. Omari (2018) the use of divergent type questions which is similar with open-ended questions were frequently used by teacher in developing the students' critical thinking. Using divergent questions can be seen as an effective way of developing students' critical thinking, which is very necessary in this $21^{\text {st }}$ century learning (Yu et al., 2019). The use of divergent questions can also build an active classroom compared to yes/no questions (Prasetianto, 2019).

The most least questions used by English teacher was yes/no question. Yes/no questions was used $32(17,68 \%)$ times during three observations of the teaching and learning process. The example of yes/no question asked by teacher are "are you ready", "do you understand?", and "have you done your homework?". According to the teacher, those questions are used to clarify and check students' understanding. This type of questions are categorized to a low level questions. Farahian and Rezaee (2012) state that a low level of questions were not effective in raising students' awareness, curiosity, motivation and critical thinking. This was also supported by Omari (2018) who state that yes/no questions was the most ineffective questioning strategy in developing students' critical thinking and problem solving skill.

\section{Conclusion}

This study concludes that there are three types of questions used by English teacher in teaching English as a foreign language namely yes/no, convergent, and divergent questions. The most frequent question used was convergent questions. It was also identified that the teachers expressed a number of reasons for using questions such as to check students' understanding, clarifying, raising students' curiosity and developing students' critical thinking. This study suggests that the English teachers should use different of questioning skills in order to keep the classroom to be active. The use of divergent questions are encouraged more in order to develop students' critical thinking skill which is very important in this $21^{\text {st }}$ century. Further study is encouraged to analyse the difficulties encountered by English teacher in using types of questions and how to deal with the students' answer.

\section{References}

Aqil, M. H. (2017). Analyzing Teacher's Questions in Reading Activity. Ninth International Conference on Applied Linguistics, 285-288. https://doi.org/10.2991/conaplin-16.2017.64

Astrid, A., Amrina, R., Desvitasari, D., Fitriani, U., \& Shahab, A. (2019). The Power of Questioning : Teacher ' s Questioning Strategies in the EFL Classrooms. Indonesian Research Journal in Education, 3(1), 91106. https://online-journal.unja.ac.id/irje/article/download/6601/4195.

Crowe, S., Cresswell, K., Robertson, A., Huby, G., Avery, A., \& Sheikh, A. (2011). The case study approach. BMC Medical Research Methodology, 11(1), 1-9. https://doi.org/10.1186/1471-2288-11-100

Döş, B., Bay, E., Aslansoy, C., Tiryaki, B., Çetin, N., \& Duman, C. (2016). An analysis of teachers ' questioning strategies. Educational Research and Reviews, 11(22), 2065-2078. https://doi.org/10.5897/ERR2016.3014

Erlinda, R., \& Dewi, S. R. (2014). Teacher 's questions in EFL classroom. Ta'dib, 17(2), 177-188. 
http://dx.doi.org/10.31958/jt.v17i2.271

Etemadzadeh, A., Seifi, S., \& Far, H. R. (2013). The role of questioning technique in developing thinking skills : The ongoing effect on writing skill. Procedia - Social and Behavioral Sciences, 70, 1024-1031. https://doi.org/10.1016/j.sbspro.2013.01.154

Farahian, M., \& Rezaee, M. (2012). A case study of an EFL teacher 's type of questions : an investigation into classroom interaction. Procedia - Social and Behavioral Sciences, 47, 161-167. https://doi.org/10.1016/j.sbspro.2012.06.631

Kalantari, R. (2009). Techniques for Classroom Interaction. International Journal of Language Studies, 3(4), 425-434.

Kao, S.-M. (2012). “Do You Understand?”: An Analysis of Native and Non-native EFL Teachers' Questioning Patterns at a Taiwanese Cram School. Asian EFL Journal, 14(4), 39-68. http://www.academia.edu/download/30295197/Questioning2012_AEFL14.pdf.

Liskinasih, A. (2016). Corrective Feedbacks in CLT-Adopted Classrooms' Interactions. Indonesian Journal of Applied Linguistics, 6(1), 60-69. https://doi.org/10.17509/ijal.v6i1.2662

Merriam, S. B., \& Tisdell, E. J. (2016). Qualitative Research: A Guide to Design and Implementation. JosseyBass.

Miles, B., Huberman, M., \& Saldana, J. (2014). Qualitative Data Analysis: A Methods Sourcebook. SAGE Pub.

Nurpahmi, S. (2017). Teacher talk in classroom interaction. Eternal Journal, 3(1), 35-43. https://www.researchgate.net/profile/Sitti_Nurpahmi/publication/323340494_TEACHER_TALK_I N_CLASSROOM_INTERACTION/links/5af8395caca2720af9e274ac/TEACHER-TALK-INCLASSROOM-INTERACTION.pdf

Omari, H. A. (2018). Analysis of the Types of Classroom Questions Which Jordanian English Language Teachers Ask. Modern Applied Science, 12(4), 1-12. https://doi.org/10.5539/mas.v12n4p1

Padmadewi, N. N., Artini, L. P., \& Agustini, D. A. E. (2017). Pengantar Micro Teaching. Rajawali Press.

Paramartha, A. A., Ramawati, N. M., \& Suputra, P. . (2018). Types, Purpose, and Strategies of Teacher's Questions in Indonesian EFL Classroom of Junor High School in Bali. International Journal of Language and Literature, 2(1), 8-18. http://dx.doi.org/10.23887/ijll.v2i1.16089

Prasetianto, M. (2019). Kinds of Questions Making EFL Students Learn: Students' Perception. Journal of Applied Linguistics and Literature, 4(2), 162-176. https://doi.org/10.33369/joall.v4i2.7607

Qashoa, S. (2013). Effects of teacher question types and syntactic structure on EFL classroom interaction. The International Journal of Social Sciences, 7(1), 52-62.

Rachmawaty, N., \& Ariani, S. (2019). Investigating the Types of Teacher Questions in EFL Secondary Classroom. 6th International Conference on English Language and Teaching, 40-49.

Rido, A., \& Sari, F. M. (2018). Characteristics of Classroom Interaction of English Language Teachers in Indonesia and Malaysia. International Journal of Language Education, 2(1), 40-50. https://doi.org/10.26858/ijole.v2i1.5246

Sari, N. P., \& Hasibuan, W. F. (2019). Teacher's questioning skills and students' responses in science subject based on parenting style perspectives. Jurnal Pendidikan Biologi Indonesia, 5(1), 85-92.

Shaunessy, E. (2005). Questioning strategies for teaching the gifted. Prufrock Press Inc.

Sundari, H. (2017). Classroom Interaction in Teaching English as Foreign Language at Lower Secondary Schools in Indonesia. Advances in Language and Literary Studies, 8(6), 147-154. https://doi.org/10.7575/aiac.alls.v.8n.6p.147

Usenbo, P. (2017). Yes/No questions in È dó: The markers Perpetual Usenbo. De Gruyter Open, 1-20. https://doi.org/10.1515/qal-2017-0001

Vebriyanto, D. A. (2015). Teacher's Questions in EFL Classroom Interaction. Journal Vision, 4(2), 279-303. https://journal.walisongo.ac.id/index.php/vision/article/viewFile/1595/1173

Vusparatih, D. S. (2014). Peranan Komunikasi Guru dalam Implementasi Kurikulum 2013. Humaniora, 5(1), 387-397. https://journal.binus.ac.id/index.php/Humaniora/article/viewFile/3037/2426 
Yang, C. C. R. (2010). Teacher Questions in Second Language Classrooms: An Investigation of Three Case Studies. Asian EFL Journal, 12(181-201). http://70.40.196.162/PDF/March-2010.pdf\#page=181

Yu, T. X., Muna, W., \& Wan, R. (2019). Integration of 21st Century Learning Skills ( 4C Elements ) in Interventions to Improve English Writing Skill Among 3K Class Students. International Journal of Contemporary Education, 2(2), 100-121. https://doi.org/10.11114/ijce.v2i2.4498

Zulkifli, H., \& Hashim, R. (2019). The Development of Questioning Skills through Hikmah ( Wisdom ) Pedagogy. Creative Education, 10, 2593-2605. https://doi.org/10.4236/ce.2019.1012187 